\title{
The Inflectional Type of Verb to Noun and Noun to Verb Zero Derivation in Macedonian
}

\author{
Marjana Vaneva, PhD \\ University American College Skopje, School of Foreign Languages \\ Email: vaneva@uacs.edu.mk
}

\section{Doi:10.5901/mjss.2013.v4n3p545}

\section{Abstract}

This paper studies the process of zero derivation in which from a lexeme that belongs to one lexical category, by using metaphoric transfer, a new lexeme is derived, with expanded meaning, with a form changed from inflectional point of view, thus becoming a member of another word class. In this way, the lexeme before and the one after the process belong to different lexical categories, so that zero derivation happens when, as the process requires, nothing derivational is used, but the suffixes which are used for this phenomenon and that are being added, replaced or dropped are of inflectional type. This notion is a characteristic of Macedonian because this Slavic language is rich in inflectional suffixes and that aids the zero derivation, since all the conditions for the process are met: the meaning is expanded, the word class is changed while the form is changed as much as the process allows, that is, only when inflections are used. Of the several types and directions, the paper studies two: from verb (both imperfective and perfective) to noun and vice versa, from noun to verb (imperfective and perfective). Thus, the examples and the analysis will show which inflectional material is used and what the meaning of the new lexeme is, after the process finishes. Therefore, several subtypes of inflectional zero derivation in these two directions will be distinguished, and a metaphoric-cognitive transfer is used to illustrate not only the existence but, more importantly, the productivity of the process in Macedonian.

Keywords: inflectional suffixes, noun, verb, Macedonian

\section{Introduction}

This type of zero derivation, which is derivation by a zero suffix, besides the given name inflectional, can be also described with the terms untypical or morphological because the lexemes that are analysed for the purpose of this process can go through morphological changes, that is, the form of one of the lexemes in question is molded or changed by adding inflectional suffixes to the motivating basis, or by changing or dropping some suffixes that show the citation form of the derived lexeme - the one that goes through the process of zero derivation.

There are several authors in the Macedonian linguistics who investigate the change of the lexical category in Macedonian by using zero affix. Namely, Blaze Koneski (Блаже Конески 1967) in his grammar gives word formation description of the Macedonian language, which is important not only for the Macedonian language study, but also for the Slavic comparative word formation. Kiril Koneski (Кирил Конески, 1987, p. 51-60) explains zero derivation of verbs from nouns and he distinguishes several subtypes within one direction of the process. According to him, the important characteristic that lies in the basis of this derivation is the motivated connection between the words which belong to different lexical categories, having the basic word on one side and the derived one on the other side. The same author, Kiril Koneski (Кирил Конески, 1995, р. 19), is among the first in the study of the Macedonian language who uses the term zero affix, and explains that a zero derivational and inflectional suffixes are added to the motivating basis so that at the end of the process a new zero derivational lexeme is produced.

As opposed to English, where, according to Quirk (1995), the process of zero derivation is derivation whereby the lexeme goes from one lexical category into another without use of an affix, a definition that applies to all analytic languages, in Slavic language structures, which are synthetic and of an inflectional type, the process of zero derivation happens with inflectional intervention. Therefore, it is important to consider and accept the interpretation that Stela Manova and Wolfgang Dressler give in Bauer and Valera (2005, p. 72), when they claim that with this process the word class changes without adding any derivational material, but rather by adding, replacing or dropping inflectional suffixes. This explanation fully complies with the aim of the paper - to demonstrate the important role of the inflectional suffixes in the process of zero derivation in Macedonian. 
In this language, the productive zero derivation, which is represented with this inflectional type, can be illustrated with the following changes of the lexical category: from verb to noun, from noun to verb, from adjective to verb, and from verb to adjective. Regarding the way in which the lexemes in each direction are analysed, they are classified according to the type of the inflectional material that, together with the motivating basis, participates in the process of zero derivation of lexemes. Thus, in each direction there are subgroups depending on the fact whether there are elements that result from adding inflectional suffixes to the basis, when the suffixes of one of the lexemes are replaced with other suffixes, or these suffixes are left out from the starting lexeme and in that way the structure of the new, derived lexeme overlaps with the form of the motivating basis. In this paper, the focus will be on two types of inflectional zero derivation in Macedonian: from verb to noun and from noun to verb.

\section{Inflectional Verb to Noun Zero Derivation in Macedonian}

This group will analyse the verb lexemes that have been transformed into nouns through the process of zero derivation. Hereby, two grammatical aspects of the verb - imperfective and perfective - will be analysed as basis for zero derivation into noun.

\subsection{Inflectional zero derivation from imperfective verb into noun}

In this subgroup, depending on the type of the inflectional material, the lexemes are subdivided and different formulas are applicable.

2.1.1 The following elements correspond with the first subgroup:

L1 V (=MB+ØDS+IS- $u) \rightarrow$ L2 N (=MB+ØDS+IS-a) ${ }^{1}$

This subgroup of the process is represented by the following lexemes:

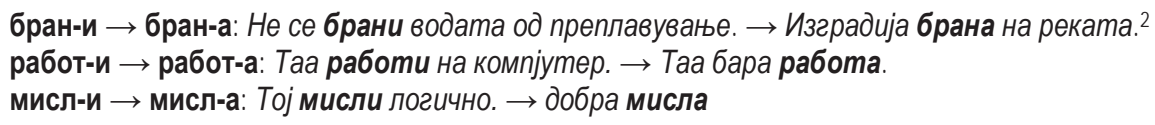

In these examples, the relationship between the noun and the verb is very close and easily understandable. The verb брани means to build fence around the water in order to prevent it from spreading or flooding, while the thing that is put in order to stop the water from spreading or flooding is explained with the noun брана. This means that first the action happens and then the noun is formed, which proves that the direction of the zero derivational process is indeed from verb to noun. The same thing happens in the other examples when by working, doing something - работа is formed, while by thinking, the product is мисла.

2.1.2 The second subgroup illustrates a different change, which can be seen from the formula:

\section{L1 V (=MB+ØDS+IS-a/-e/-u) $\rightarrow$ L2 N (=MB+ØDS)}

вик-а $\rightarrow$ вик: Некој вика во дворот. $\rightarrow$ Слушнав силен вик.

премин-е $\rightarrow$ премин: Сам не може да ја премине улицата. $\rightarrow$ Наидов на голем премин.

чекор-и $\rightarrow$ чекор: Таа чекори ситно и брзо. $\rightarrow$ Таа има ситен чекор.

\footnotetext{
${ }^{1}$ In this, and in the following schemes, the interpretation of the symbols is as follows: $\mathrm{L} 1=$ lexeme $1, \mathrm{~L} 2=$ lexeme $2, V=$ verb, $N=$ noun, $\mathrm{MB}=$ motivating basis, $\varnothing=$ zero, $\mathrm{DS}=$ derivational suffix, IS = inflectional suffix.

${ }^{2}$ In all example structures, the analysed lexemes (the ones listed before the example phrases and sentences) have been taken from the Macedonian dictionaries consulted for the research. They are: Речник на македонскиот јазик со српскохрватски толкувања, Речник на македонската народна поезија, and Толковен речник на македонскиот јазик. Their full references are given on the reference page.
} 
Here, again the semantic transfer moves from verb to noun when, as the name of this entire group is, the action is performed first. Thus, by doing the action, we get the result, that is, the noun shows the thing that is made by doing the action or by conducting the event. But, opposed to the first subgroup where the inflectional suffix $-u$ from the source lexeme is replaced with the suffix $-a$ in the new lexeme; in this, second subtype, the $-a,-e,-u$ inflection that forms the starting lexeme together with the motivating basis and the zero derivational suffix, is being dropped and thus the result of the process is created.

In this way, the new lexeme is absolutely identical with the motivating basis.

The following figure ought to show graphically the semantic transfer and the lexical and functional change in the lexemes that take part in this kind of transformation:

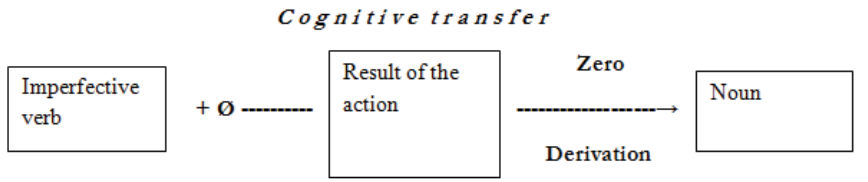

Figure 1: Inflectional zero derivation in Macedonian: from imperfective verb into noun

\subsection{Inflectional zero derivation from perfective verb into noun}

2.2.1 The formula for this kind of derivation is the following one:

\section{L1 V (=MB+ØDS+|S-u) $\rightarrow$ L2 N (=MB+ØDS+IS-a)}

These are examples of this type:

навред-и $\rightarrow$ навред-а: Твојот збор ја навреди. $\rightarrow$ Тоа беше голема навреда за мене. покан-и $\rightarrow$ покана-а: Тој сам се покани. $\rightarrow$ добив судска покана.

The first example on the left shows the verb навреди which means to say something bad and insult somebody, from which the noun навреда is formed and means the thing that is being said is bad and insulting. The sentences with покани $\rightarrow$ покана are also very similar; from the imperfective verb meaning to call somebody somewhere the noun покана is zero derived, and that is what is being said, or given in the act of inviting somebody. Of course, by retaining the form, the formal criterion is met, and also the semantic one, because the semantic connection enables us to treat these lexemes as examples of zero derivation. Here, again by performing the action, we experience and perceive the act that results from the performed action, and understand the concept that results from the action. Knowing the meaning of the verb, the speaker or the word creator copies or expands the semantic implication of the new lexeme that should fill the noun gap. The same happens in the following examples that are listed as part of this subgroup:

$$
\begin{aligned}
& \text { наград-и } \rightarrow \text { наград-а: Советот ги награди. } \rightarrow \text { ми врачија награда } \\
& \text { дозвол-и } \rightarrow \text { дозвол-а: Дозволи ми да се извинам. } \rightarrow \text { Само општината издава таква дозвола. } \\
& \text { посет-и } \rightarrow \text { посет-а: го посети синот } \rightarrow \text { редовна лекарска посета } \\
& \text { злоупотреб-и } \rightarrow \text { злоупотреб-а: ја злоупотреби нашата доверба } \rightarrow \text { Направија злоупотреба која скапо }
\end{aligned}
$$
ќе ги чини.

одбран-и $\rightarrow$ одбран-а: не можеше да се одбрани $\rightarrow$ Секоја одбрана беше бесполезна.

побед-и $\rightarrow$ побед-а: Со оптимизам ја победи болеста. $\rightarrow$ Победата зборува за квалитетот.

смен-и $\rightarrow$ смен-а: Го сменија раководителот. $\rightarrow$ смена на раководство

when in doing the action of giving presents to somebody, what is handed in or given is награда; in order to allow somebody to do something, a written or oral permission (дозвола) is given; the act of visiting somebody is посета; with the action of harassing somebody or something, we dо злоупотреба; the noun одбрана is an act with which we protect ourselves; in the case in which somebody is better at something than somebody else or is the first, победа is the result; 
like in the case when somebody or something leaves a certain place and is replaced with somebody or something else, the meaning of the noun смена is understood.

Otherwise, in both cases of zero derivation that were listed as transformations from imperfective and perfective verb into noun when a zero affix is used for changing the word class, the inflectional aspect of the process is obvious. This means that the replacement of the form formation suffix $-u$ from the verb with the suffix $-a$ in the zero derived noun is obvious, but also the dropping of the inflections $-a,-e$ and $-u$ from the source lexeme and zero deriving the target lexeme that consists only of motivating basis is evident. From a semantic point of view, everything that is given or received after performing the action is copied from the verb, with whose activation, the product is created, and that is our target element - the noun.

The scheme of this change is the following:

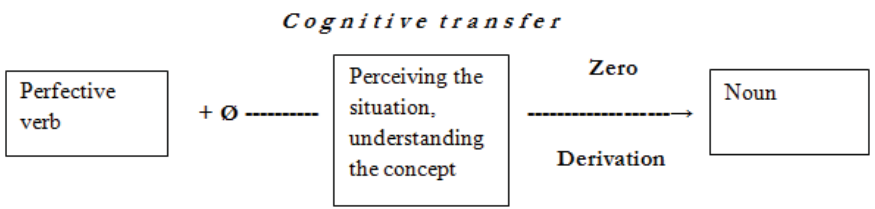

Figure 2: Inflectional zero derivation in Macedonian: from perfective verb into noun

\section{Inflectional Noun to Verb Zero Derivation in Macedonian}

The noun can be zero derived into verb of imperfective and perfective type, thus imposing formal changes. In continuation, the kind of zero derivation from noun to imperfective verb will be illustrated with formulas that correspond with different subgroups:

\subsection{Inflectional zero derivation from noun into imperfective verb}

3.1.1 Regarding the first subgroup, the following formula applies:

\section{L1 N (=MB+ØDS) $\rightarrow$ L2 V (=MB+ØDS+IS-u)}

This means that the source, noun lexeme consists of motivating basis to which a zero derivational suffix is added, while to the target, verb lexeme an inflectional suffix $-u$ is added that illustrates semantic connection and morphological similarity.

The nouns that will be first analysed mean somebody works as something or appears in the the role of and the examples illustrate formations of verbs from nouns, when the suffix $-u$ as an inflectional suffix is added to the word formation basis of the noun and, in that way, we get the dictionary, unmolded verb form. The following examples show this: заработува.

сточар $\rightarrow$ сточар-и: Соседот отиде сточар. $\rightarrow$ Едниод брат сточари во овие предели и така

стражар $\rightarrow$ стражар-и: Фирмата вработи еден стражар. $\rightarrow$ Соседот стражари на граница.

печалбар $\rightarrow$ печалбар-и: Тој е цел живот печалбар. $\rightarrow$ Тој одамна печалбари во Германија.

In the examples from this subgroup the noun means the subject works as something, and the verbal derivative means to have the function denoted with the noun. Thus, in the first example, from the noun сточар - a person who breeds cattle and earns for a living, we derive the verb сточари - to be a cattle breeder.

But, in the next group of examples, noun-verb transformations stand out when the noun doesn't mean function and job but a characteristic that the subject has, whereas the verb means applying the characteristic denoted with the noun while performing the action. Such examples are:

ситничар $\rightarrow$ ситничар-и: Тој е вистински ситничар. $\rightarrow$ Тој секогаш ситничари.

сплеткар $\rightarrow$ сплеткар-и: Не нй треба сплеткар. $\rightarrow$ Таа не работи ништо, само сплеткари.

кодош $\rightarrow$ кодош-и: Не му верувај, тој е кодош. $\rightarrow$ Тој постојано кодоши. 
The last example proves the previously said: when somebody is а кодош, that person spies, tells others secrets and information, so that when the person does the action illustrated with кодоши, he/she displays this characteristic, feature, that is, behaves like а кодоu.

There are also nouns that transformed to verbs imply the subject to become what is named with the basic noun, as the following examples show: вампири.

вампир $\rightarrow$ вампир-и: Немам видено поголем вампир. $\rightarrow$ Не знам ито му е - нешто почна да се

вештер $\rightarrow$ вештер-и: изгледа како вештер. $\rightarrow$ Кога ќе слушне за тоа, се вештери.

побратим $\rightarrow$ побратим-и: стар побратим $\rightarrow$ Соседот се побратими со скараниот пријател.

The noun вештер refers to a bad and evil person, and when we use the zero derived verb, the interpretation is that the person is changing, is becoming bad. In our example above it is used reflexively.

Another subgroup is the case when the subject displays the characteristic or the feature typical of the source noun formed from animals, while the verb means to display a feature of what is denoted with the basic noun:

сокол $\rightarrow$ сокол-и: Соколот е симбол за храброст и моќ. $\rightarrow$ Се соколи со добрите вести.

петел $\rightarrow$ петел-и: се прави петел во оваа работа $\rightarrow$ Се петели штом ја прашуваш за совет.

This last example can be explained by saying that the noun петел implies pride, significant status, someone who feels conceited, likes showing off, and by analogy the verb се петели means somebody to behave in this way - like a cock (nетел), that is, to like showing off, to like being proud, conceited, important.

The next example:

маж $\rightarrow$ маж-и: дојде еден маж $\rightarrow$ Се мажи девојката.

shows that in the speaker's mind this noun lexeme is zero derived in a verb having the meaning to marry a man, which is illustrated with the example on the right.

On the other hand, by combining the noun калап and the verb, we get a derivative that means to put or place something into the object denoted with the noun:

калап $\rightarrow$ калап-и: користат калап за чевли $\rightarrow$ Работничката ги калапи артиклите.

This noun stands for an enclosed space or object, from whose basic meaning by association leaps in the meaning of the domain object, that is, space or object we come to the domain of the verb with whose action the object is placed in the noun.

A different subgroup of verbs that are zero derived from nouns and means to do or to create the thing denoted with the noun is the following:

пласт $\rightarrow$ пласт-и: Утрово падна голем пласт снег. $\rightarrow$ Силен ветер го пласти снегот.

To this group also belong nouns that mean the process to finish by creating something that the noun names, and by analogy, the verbs transformed from them mean to create the thing that the noun names:

пожар $\rightarrow$ пожар-и: Избувна пожар на повеќе места. $\rightarrow$ Пожар го пожари местото.

пустош $\rightarrow$ пустош-и: Пустош го зафрати регионот. $\rightarrow$ Пожар ја пустоши шумата.

Thus, in the first-listed example from the noun пожар, in the speaker's mind there is picture of the verb пожари which means fire breaks out, and the same semantic transfer is present in the other example where the following interpretations are developed: да пустоши - to devastate, to destroy.

Besides the verbs derived in this way, there are such which are motivated mainly from onomatopoeic words, that is, from nouns which become imperfective verbs. Naturally, these verbs are formed when the inflectional suffix $-u$ is added to the motivating basis and mean to create or introduce the notion denoted with the nominal sound complex. Such examples are:

молскот $\rightarrow$ молскот-и: Сношти имаше страшен молскот. $\rightarrow$ молскоти небото

трескот $\rightarrow$ трескот-и: силен трескот $\rightarrow$ Силен земјотрес ја трескоти Европа.

шепот $\rightarrow$ шепот-и: Се слуша далечен шепот. $\rightarrow$ Не можам да ја слушам кога шепоти.

џагор $\rightarrow$ џагор-и: Везден се слуша цагор. $\rightarrow$ нагори водата. 
The noun шепот means an act of saying something quiet and therefore it is thought that the verb can be used with a similar meaning, derived and transferred from the meaning of the noun, which means to say something quiet, without using voice.

On the other hand, the verbs соли, шеќери and бибери zero derived from nouns mean to apply the ingredient, substance denoted with the noun, and this can be seen in the following examples:

сол $\rightarrow$ сол-и: Додај му сол на јадењето. $\rightarrow$ го соли јадењето.

шеќер $\rightarrow$ шеќер-и: Стави шеќер во чајот! $\rightarrow$ го шеќери чајот.

бибер $\rightarrow$ бибер-и: Има ли бибер во јадењето? $\rightarrow$ ја бибери супата.

This means that the verb implies to use salt (сол), sugar (шеќер) or pepper (бибер) in order to do the action; actually, by applying them, we understand what the verb means.

Besides these, there are verbs derived from nouns which mean to be in the state marked with the noun or to display the feature named with the basic noun:

пркос $\rightarrow$ пркос-и: Треба да му се спротивставиш на пркосот во животот. $\rightarrow$ И покрај сите лични проблеми, таа му пркоси на животот.

ужас $\rightarrow$ ужас-и: Во последно време нѐ погоди голем ужас. $\rightarrow$ Се ужасив од тоа што го слушнав. something.

This last example proves that the verb ужаси means to be in a state of terror, to feel terror from or towards

There are other nouns from the colloquial language which can be used with the verb прави, and when used as verbs mean to do the thing contained in the basic noun:

мајтап $\rightarrow$ мајтап-и: Многу често прави мајтап на своја сметка. $\rightarrow$ Tој се мајтапи со тебе.

муабет $\rightarrow$ муабет-и: Прави муабет за новонастанатата ситуација. $\rightarrow$ Таа муабети со соседите.

резил $\rightarrow$ резил-и: пукна резил $\rightarrow$ Не е убаво да се резили пред луѓето.

The meaning of these sentence structures used as an example is that by playing about we perform the action of мajmaneњe, by talking we perform the action of муабеmeњe, as when embarrassing somebody, we do the action of резилење. Namely, these examples undoubtedly lead us to the fact that we first know the noun and by trying to use it or create it, we perform and perceive the action denoted with the verb.

3.1.2 The formula that is applicable to the second type of inflectional zero derivation from noun to imperfective verb is given in continuation:

\section{L1 N (=MB+øDS+IS-a) $\rightarrow$ L2 V (=MB+ØDS+IS-u)}

жен-а $\rightarrow$ жен-и: Дојде една жена. $\rightarrow$ Соседот се жени.

куќ-а $\rightarrow$ куќ-и: Направија нова куќа. $\rightarrow$ Се куќи новиот станар.

пудр-а $\rightarrow$ пудр-и: Става пудра на лицето. $\rightarrow$ го пудри лицето

Here the meaning of the zero derived verb is to marry a woman, to put someone in closed space and to perform the action by applying something, respectively, that was mentioned in the previous inflectional type of this kind of zero derivation, but in this case the inflectional suffix -a from the source lexeme is replaced with $-u$ in the target one.

Otherwise, in this subgroup, as was the case with zero derivation from singular noun into a verb, there are also nouns that mean to perform the action with the use of the noun. Such are the following:

труб-а $\rightarrow$ труб-и: се слушна звук од труба. $\rightarrow$ Тој труби веќе четири години.

гусл-а $\rightarrow$ гусл-и: Се научи да гусла. $\rightarrow$ Тој гусли уште од мал.

пил-а $\rightarrow$ пил-и: работи со пила $\rightarrow$ ја пили вратата

These derived verbs point out that in order to do the action труба, гусла and пила are used, and we conclude that what connects the lexemes from both sides of the example from the previously given structures is the fact that knowing the concept for these objects, the previous knowledge and the experience lead us to zero derivation of a verb, which means using the object denoted with the noun.

The examples with молитви and клевети belong to this same type of zero derived verbs, because as verb lexemes these derivatives mean to use or say prayers and curses for doing the action: 
молитв-а $\rightarrow$ молитв-и: кажуваат молитва $\rightarrow$ Тој молитви за среќа и доле живот.

клевет-а $\rightarrow$ клевет-и: кажува клевета $\rightarrow$ Раководителот ги клевети вработените.

It can also be noticed that in this type of zero derivation with this cognitive approach and metaphoric transfer, as derivatives, we get both transitive and intransitive verbs, which can be seen from some of the given examples:

гриж-а $\rightarrow$ гриж-и: Грижата ја промени целосно. $\rightarrow$ Многу се грижи за семејството.

бразд-а $\rightarrow$ бразд-и: направи голема бразда $\rightarrow$ Кожата се бразди од неволји.

солз-а $\rightarrow$ солз-и: Голема солза изрони. $\rightarrow$ Окото ми солзи.

мреж-а $\rightarrow$ мреж-и: фррла мрежа во реката $\rightarrow$ Ми се мрежи окото.

In all these cases, knowing the noun from which the zero derivation starts, we can perceive the verb and do the action.

In the following cases:

зор-а $\rightarrow$ зор-и: Cnиј, уште е зора. $\rightarrow$ Веднаш штом почне да зори ги отвораат дуќаните во чаршијата.

магл-а $\rightarrow$ магл-и: Магла се спушти над полето. $\rightarrow$ Се магли небото.

слан-а $\rightarrow$ слан-и: Промените во температурата направија слана да ги зафрати овошките. $\rightarrow$ Слана ли слани по полето?

the verb derivatives mean natural phenomena to happen that are named by the noun contained in the basis. Thus, their meaning, that is, what they have in their semantic domain is: to dawn, to befog, to cover with frost, from which we again get reflexive verbs: зори and магли.

As a different and last subgroup listed in this type of zero derivation is the one that means to breed, to give birth to animals; something that is illustrated with the reflexive verbs кози and крави:

коз-а $\rightarrow$ коз-и: Соседите чуваат коза на фрармата. $\rightarrow$ Козата се кози.

крав-а $\rightarrow$ крав-и: Видов една крава во ливадата. $\rightarrow$ Нашата крава ќе се крави на пролет.

And, of course, the implication is to breed goat, cow, when from the animals коза (goat) and крава (cow), with semantic transfer we are taken to the verb domain, which means breeding this animal.

3.1.3 The replacement of the inflectional suffix is also shown in the following subtype, to which this formula applies:

\section{L1 N (=MB+ØDS+IS-e) $\rightarrow$ L2 V (=MB+ØDS+IS-u)}

Here, mainly, belong verbs that are derived from nouns that name animals:

ждреб-е $\rightarrow$ ждреб-и: Нашето ждребе се вика Сивко. $\rightarrow$ Нй се ждреби кобилата.

јагн-е $\rightarrow$ јагн-и: мирен како јагне $\rightarrow$ Овцата се јагни.

пил-е $\rightarrow$ пил-и: едно пиле $\rightarrow$ кокошката се пили

прас-е $\rightarrow$ прас-и: нашето прасе $\rightarrow$ Се праси свињата.

In this case, as the form shows, the inflectional suffix -e added to the motivating basis, and to the zero derivational suffix in the starting lexeme - the noun, is replaced with the suffix $-u$ at the ending lexeme - the verb. Otherwise, the metaphoric-cognitive transfer creates the semantic connection between the two lexemes and makes the noun and the verb connected through the process of zero derivation.

3.1.4 In the last inflectional type the -0 inflection is replaced with $-и$ :

\section{L1 N (=MB+ØDS+IS-o) $\rightarrow$ L2 V (=MB+ØDS+IS-u)}

The following will be listed as examples of this type:

стакл-о $\rightarrow$ стакл-и: Мајсторот става стакло на терасата. $\rightarrow$ Тој ја стакли терасата.

сребр-о $\rightarrow$ сребр-и: ковано сребро $\rightarrow$ Продавачот го сребри сервисот за јадење.

злат-о $\rightarrow$ злат-и: бело злато $\rightarrow$ Златарот ги злати обетките.

The interpretation for the zero derivation in the first example is that from the noun whose meaning is familiar to us, by using zero affix, we get a verb that means to do the action by using the noun. The same meaning of the derivative was 
mentioned before too, but now it is repeated and emphasized because the lexemes which are analysed have different form, that is, they belong to a different inflectional type of zero derivation.

In this group also, the basic words are nouns that are most often used with a verb or can be modified by an adjective, while the result of the metaphoric transfer is an imperfective verb surrounded by short pronominal forms, by the reflexive pronoun $c e$, as well as by nouns and prepositional phrases which complement the verb. Actually, in this type of zero derivation, the lexemes listed before the examples are given in their dictionary form. This means the words can accept inflectional suffixes: the noun can have an article, whereas the verb can be given inflections for tense, type (perfective or imperfective), voice, gender, number and thus for a person who does the action.

As far as the semantic level is concerned, the noun is the one that first exists in the language and in the speaker's mind, so that in most cases by using that noun or by making a picture of it, we perceive the verbal action, something that is expressed with the newly formed lexeme.

The development and the diversification of the meaning in this type of zero derived verbs are shown with the following figure:

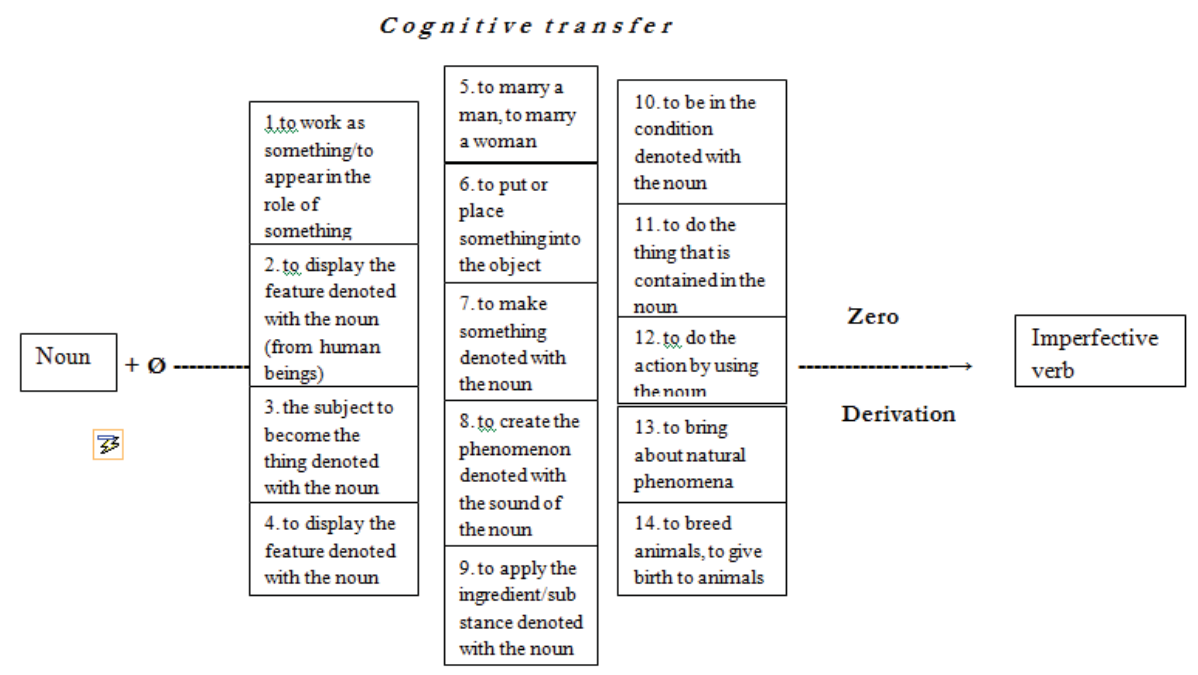

Figure 3: Inflectional zero derivation in Macedonian: from noun into imperfective verb

\subsection{Inflectional zero derivation from noun into perfective verb}

In Macedonian there are a small number of perfective verbs derived from nouns by zero derivation because in order to form verbs of this type prefixes should be added, and this type of word formation is with the use of zero affix, actually derivation without affixation. This characteristic, the presence of prefixes, is what marks and distinguishes the perfective verbs from the imperfective ones, and thus their form is not identical with the noun. Therefore, in continuation we will give the most common elements of this subtype and, of course, take them to be result of this word formation process in Macedonian. This type has the formula with which most of the examples in Macedonian comply, and that is when the form formation suffix $-u$ is added to the motivating basis with zero derivational suffix:

\section{$\mathrm{L} 1 \mathrm{~N}(=\mathrm{MB}+\varnothing \mathrm{DS}) \rightarrow \mathrm{L} 2 \mathrm{~V}(=\mathrm{MB}+\varnothing \mathrm{DS}+\mathrm{IS}-u)$}

3.2.1 Thus, most verbs from this group mean to do the action whose feature is imposed by the noun. Such examples are the following:

$$
\begin{aligned}
& \text { поздрав } \rightarrow \text { поздрав-и: примете голем поздрав } \rightarrow \text { Претседателот ги поздрави присутните. } \\
& \text { причест } \rightarrow \text { причест-и: Луѓето чекаат за причест. } \rightarrow \text { Попот ги причести луѓето. } \\
& \text { сојуз } \rightarrow \text { сојуз-и: Двете завојувани земји склучија сојуз. } \rightarrow \text { Тој се сојузи со противникот. }
\end{aligned}
$$


The interpretation is that when somebody sends greetings, that person does the action of поздравување; when Communions are given, the people do the action of nрuчестување and by making unions, we do and perceive the action of сојузење.

3.2.2 Namely, here we have nouns which, by being used as a basis for deriving verbs, are transformed into verbs which show that by doing the action, the person/the doer becomes what is denoted with the noun. Very often these verbs are used as reflexive, like in the following example:

побратим $\rightarrow$ побратим-и: стар побратим $\rightarrow$ Тој се побратими со скараниот пријател.

The semantic aspect is the same: it is the noun that makes it possible for the action to be done and makes it easier to understand the semantic relationship between it - the noun, and the verb.

Here is the scheme of this subgroup:

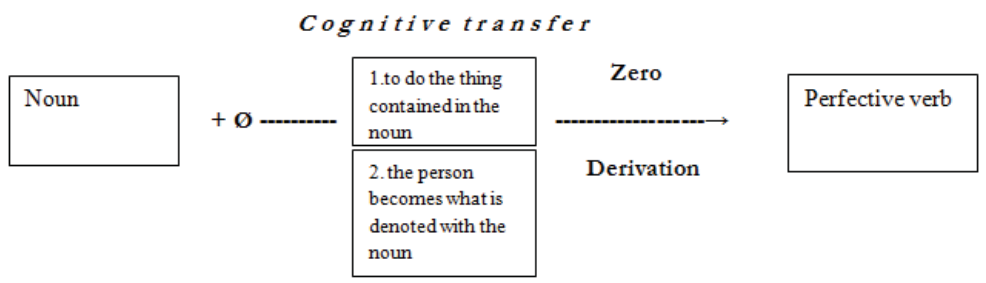

Figure 4: Inflectional zero derivation in Macedonian: from noun into perfective verb

\section{Concluding remarks}

The inflectional zero derivation in Macedonian shows that the elements that are used in the process have different form, that is, both lexemes are taken in their citation form from a dictionary, but they are different by their form formation suffix, which is added, replaced or dropped in the derived lexeme. The process is also called morphological because from a word from one lexical category, a linguistic element that belongs to another lexical category is zero derived, and that change is not derivational, since nothing derivational is used, but it is rather inflectional, when only the allowed inflectional material is applied. In Macedonian, this change of word classes with the use of a zero affix is at a level of realization, of marked forms, since in this type of the process in Macedonian, the conditions for zero derivation are met only when the analysed lexeme undergoes inflectional changes.

When talking about the two types of this inflectional kind of the process in the two chosen directions - from verb to noun and from noun to verb, we can conclude that Macedonian is a verbal language, meaning that in this language there are more verbs from which nouns are derived. This language feature is due to the nature of the language, its rich verbal system and the need to fulfill, enrich and expand the noun part of the language.

Such derivation from verb to noun is characterized by the subtype from imperfective verb to noun, when the verb consists of motivating basis, zero derivational suffix, and an inflectional suffix $-u$, when the last is replaced with $-a$, as in бразд-а $\rightarrow$ бразд-и. But these inflectional suffixes can be dropped in the derivative so that the new lexeme formally overlaps with the motivating basis: вик-а $\rightarrow$ вик. Also, in the zero derivation from perfective verb into a noun, the suffix $u$ is replaced with $-a$, as in навред-и $\rightarrow$ навреда-а.

As far as the zero derivation from noun to verb is concerned, the inflectional type is also represented by transformations from imperfective verb to noun and from perfective verb into a noun lexeme. The imperfective verb zero derived from a noun is received when the inflectional suffix is added to the motivating basis - сточар $\rightarrow$ сточар-и, while in the other cases the $-a$ is replaced with $-u-$ жен-а $\rightarrow$ жен-и, $-e$ is replaced with $-u-$ ждреб-е $\rightarrow$ ждреб-и, and -0 with $-u-$ стакл-о $\rightarrow$ стакл-и. The perfective verb produced from a noun through zero derivation adds the inflectional suffix $-u$ to the motivating basis - поздрав $\rightarrow$ поздрав-и.

In all these cases there is semantic connection between the two lexemes, that is, the meaning is expanded, which can be perceived by using metaphoric-cognitive transfer; the form is absolutely identical from derivational point of view, when only inflectional material is used for the purpose of this process, and most importantly, the source and the target lexeme are members of different lexical categories. 
Finally, it ought to be emphasized again that the process of zero derivation in Macedonian is highly productive due to the inflectional suffixes that mark this kind of transformation in a very economic, understandable, but also creative and modern way. In all lexemes the process happens in such a way that the inflectional suffixes are removed and what remains is the motivating basis. If in such removing of the inflections, semantic similarity and metaphoric connection are found between the roots of the word from both sides of the process, then the process in question is undoubtedly lexical change with zero affix. Then inflections typical of the Macedonian lexical categories are added, replaced or dropped so that the new lexeme, result of the zero derivational process, adapts to the requirements of the new word class and becomes a representative of the inflectional type of zero derivation in Macedonian, illustrating the necessary changes in the appropriate direction.

\section{References}

Bauer, L. \& Valera, S. (2005). Approaches to Conversion/Zero-Derivation. Münster: Waxmann Publishing Co.

Конески, Б. (1967). Граматика на македонскиот литературен јазик: дел I и II. Скопје: Бона.

Конески, К. (1987). „Од проблематиката на зборообразувањето на глаголите во македонскиот јазик” In Предавања на XIX Семинар за македонски јазик, литература и култура; Скопје и Охрид, 8-28. VIII 1986 година, Универзитет „Кирил и Методиј”, Скопје: Семинар за македонски јазик, литература и култура, 51-61.

Конески, К. (1995). Зборообразувањето во современиот македонски јазик. Скопје: Бона.

Quirk, R. (1995). Grammatical and Lexical Variance in English. London and New York: Longman.

Речник на македонскиот јазик со српскохрватски толкувања. (1994). том: I, II, III,

редактор Блаже Конески, Скопје: Детска радост.

Речник на македонската народна поезија. $(1983,1987,1993,2001)$. том: I, II, III, IV. Скопје: Институт за македонски јазик „Крсте Мисирков".

Толковен речник на македонскиот јазик. (2003). том: I, II, III, IV, раководител на проектот д-р Снежана Велковска, Скопје: Институт за македонски јазик „Крсте Мисирков”. 